\title{
CLINICOPATHOLOGIC STUDY OF INFILTRATING CARCINOMA OF BREAST AND CORRELATION WITH THE ER/PR STATUS
}

\author{
B. Raj Siddarth ${ }^{1}$, Anil Kumar², Satish Kumar ${ }^{3}$, Nyna Sindhu' ${ }^{4}$ Bharath $^{5}$ \\ ${ }_{1}^{1}$ Associate Professor, Department of General Surgery, MGM Hospital, Warangal. \\ ${ }^{2}$ Assistant Professor, Department of General Surgery, MGM Hospital, Warangal. \\ ${ }^{3}$ Post Graduate, Department of General Surgery, MGM Hospital, Warangal. \\ ${ }^{4}$ Post Graduate, Department of General Surgery, MGM Hospital, Warangal. \\ 5 Post Graduate, Department of General Surgery, MGM Hospital, Warangal.
}

\section{ABSTRACT}

Breast carcinoma is the second most common carcinoma in women and account for $22 \%$ of all female cancers, which is more than twice the prevalence of cancer in women at any other site. Recent information suggests that globally after lung cancer, the carcinoma of the breast is the second leading cause of cancer related death and is the most common cancer among women excluding the non-melanoma skin cancers. India accounts for nearly six percent of deaths due to breast cancer in the world and also that one out of every 22 women in India are diagnosed with breast cancer every year.

The aim of this study is to determine the role of oestrogen receptor [ER] and progesterone receptor [PR] status in choice of treatment for further management of patients with breast carcinoma from December 2013 to June 2015, Medical College Warangal. Evaluation of ER and PR status with core needle biopsy and post-surgical histological specimen. Correlation of ER and PR status incidence with other prognostic factors: a) Patient age, b) Age at menarche, c) Age at menopause, d) Parity of patient, e) Tumor size, f) Number of lymph nodes.

\section{METHODS}

This study was carried out on patients admitted in the General Surgery Department, MGM Hospital, from December 2013 to June 2015, has been approved by local research ethical committee.

\section{RESULTS}

A low incidence of ER-positive and high incidence of ER-negative tumours. A higher incidence of poorly differentiated and a lower incidence of well-differentiated tumours, tumour grade was independent of age, menopausal status, histopathology and stage.

\section{CONCLUSION}

The women with oestrogen and progesterone receptor positive status can opt for hormonal therapy, which will be beneficial for them. The women with oestrogen and progesterone receptor negative status, hormonal therapy will be ineffective.

\section{KEYWORDS}

Carcinoma Breast, Oestrogen Receptor, Progesterone Receptor.

HOW TO CITE THIS ARTICLE: Siddarth BR, Kumar A, Kumar S, et al. Clinicopathologic study of infiltrating carcinoma of breast and correlation with the ER/PR status. J. Evolution Med. Dent. Sci. 2016;5(20):1025-1032, DOI: 10.14260/jemds/2016/239

\section{INTRODUCTION}

Breast carcinoma is the second most common carcinoma in women and account for $22 \%$ of all female cancers, which is more than twice the prevalence of cancer in women at any other site. ${ }^{1}$ Recent information suggests that globally after lung cancer, the carcinoma of the breast is the second leading cause of cancer related death and is the most common cancer among women excluding the non-melanoma skin cancers. ${ }^{2}$ India accounts for nearly $6 \%$ of deaths due to breast cancer in the world and also that one out of every 22 women in India are diagnosed with breast cancer every year. ${ }^{3}$ Contrary to the West, where it is more common in the elderly, it is more common at a younger age in the Indian women, who present themselves in advanced stage with poor prognostic feature and have worse outcome when compared to their counterparts in the Western Countries. ${ }^{4}$

Financial or Other, Competing Interest: None.

Submission 05-02-2016, Peer Review 16-02-2016,

Acceptance 22-02-2016, Published 09-03-2016.

Corresponding Author:

Dr. B. Raj Siddharth,

MGM, Hospital, Warangal.

E-mail: dr.rajsiddharth@gmail.com

DOI: $10.14260 /$ jemds $/ 2016 / 239$
Oestrogen plays a central role in regulating growth kinetics of a variety of cells of epithelial linings, most importantly in the breast and endometrium. Breast cancer patients whose lesions contain both oestrogen receptor [ER] and progesterone receptor [PR] have the best probability of remission following hormonal therapy (Approaching 70\%) than the group of patients whose lesions contain either receptor alone (Approximately 30\%) or very low levels of both receptors (Approximately 10\%). It has been shown that tumours expressing ER and PR tend to be better differentiated and low-grade tumours. ER negative status has been shown to be predictive of recurrence of low-stage tumours independent of tumour grade, while negative PR status is associated with a significant risk of lymph node metastasis independent of other clinicopathologic factors. 1,2,3

It has been reported that the less differentiated Grade III and IV tumours showed significantly lower levels of oestrogen and progesterone receptors in infiltrating ductal and lobular carcinoma irrespective of age. Patients younger than 53 years of age with Grade II and III infiltrating ductal carcinoma also had significantly lower levels of oestrogen 
receptors, but not of progesterone receptors when compared with those patients older than 53 years of age. 5

The oestrogen receptor is probably the most powerful predictive marker due to the genomic instability, molecular heterogeneity and clonal evolution. The treatment of breast cancer can be difficult as each case is different from the other. In breast cancer, to date relatively few markers have been reported to have established predictive power and of relevance are the well-known markers the Oestrogen Receptor (ER) and the Progesterone Receptor (PR) for selecting endocrine-sensitive breast cancers and human epidermal growth receptor HER-2 for identifying breast cancer patients with metastatic disease, who may benefit from the use of monoclonal antibodies.

The oestrogen receptor is probably the most powerful predictive marker in breast cancer management, both in determining prognosis and in predicting response to hormone therapies. Progesterone receptor is also a widely used marker, although its value is less well established. Accordingly, in the West the Immunohistochemistry (IHC) testing for Oestrogen and Progesterone Receptors (ER/PR) is now recommended as mandatory in invasive breast cancer and optional in ductal carcinoma in situ (DCIS). ${ }^{3}$

\section{OBJECTIVES OF THE STUDY}

1. Evaluation of ER and PR status with core needle biopsy and post-surgical histological specimen.

2. Correlation of ER and PR status incidence with other prognostic factors.

a. Patient age.

b. Age at menarche.

c. Age at menopause.

d. Parity of patient.

e. Tumour size.

f. Number of lymph nodes.

\section{MATERIAL AND METHODS}

\section{Source of Data}

This study was carried out on patients admitted in the General Surgery Department, MGM Hospital, from December 2013 to June 2015; 40 patients with breast carcinoma not treated by chemotherapy, radiotherapy, hormonal therapy were included.

\section{Method of Collection of Data}

The clinical information like age of the patient, age at menarche, age at menopause, parity of the patient, tumour size and number of lymph nodes were collected. The histological grading was done according to the modified Scarff-Bloom-Richardson histological grading. The Oestrogen Receptor and Progesterone Receptor immunohistochemical staining were done on the specimen and it was evaluated based on this factor to reach a prognostic conclusion.

\section{Inclusion Criteria}

- Female patients with infiltrating duct carcinoma of breast that have been sent for histological grading and ER-PR including core needle biopsy.

\section{Exclusion Criteria}

- Male patients.

- Those who have undergone any chemoreduction treatment.

\section{METHOD}

\section{History}

Each patient's detailed history was taken, specially concerning their age, age of menarche, age of menopause, parity.

\section{Examination}

The patient is examined in detail. Both the breasts are examined, especially the tumour size and lymph nodes are noted.

\section{Histopathology}

The surgical specimen or the biopsy specimen is sent for grading as per Modified Scarff Bloom Richardson and immunohistochemistry for oestrogen and progesterone receptors.

\section{RESULT}

This study was carried out on patients admitted in the Department of General Surgery, MGM Hospital, Warangal, from December 2013 to June 2015; 40 patients with breast carcinoma not treated by chemotherapy, radiotherapy, hormonal therapy were included.

\begin{tabular}{|c|c|}
\hline Age & No. of Patients \\
\hline $30-35$ yrs. & 0 \\
\hline $35-40$ yrs. & 3 \\
\hline $40-45$ yrs. & 9 \\
\hline $45-50$ yrs. & 13 \\
\hline $50-55$ yrs. & 5 \\
\hline $55-60$ yrs. & 5 \\
\hline $60-65$ yrs. & 4 \\
\hline $65-70$ yrs. & 1 \\
\hline \multicolumn{2}{|c|}{ Table 1: Shows the Age Distribution among } \\
\hline \multicolumn{2}{|c|}{ the Carcinoma Breast Patients } \\
\hline
\end{tabular}

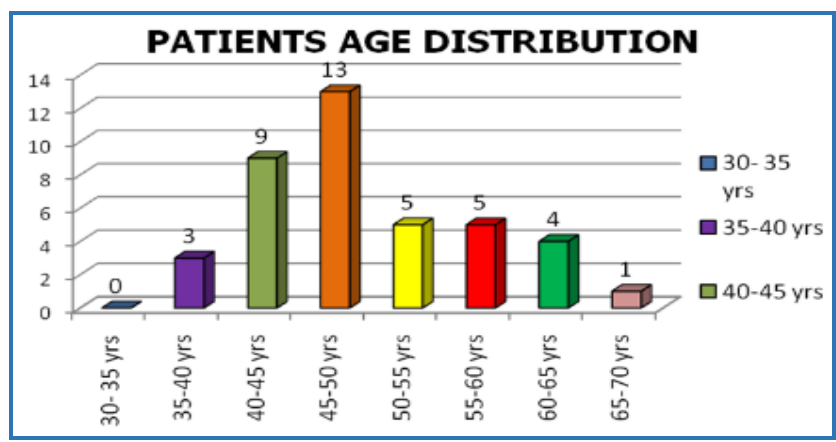

Here, the patient who took part in the study were from 35 to 70 yrs. of age, maximum people were in the age group of 45-50 yrs. The specimen from these women were sent for oestrogen and progesterone receptor status analysis. The mean age of the patients in the study is 48 yrs. and standard deviation is $+/-3.6$.

\begin{tabular}{|c|c|c|}
\hline $\begin{array}{c}\text { Age of } \\
\text { Patients }\end{array}$ & $\begin{array}{c}\text { Oestrogen } \\
\text { Receptor } \\
\text { Positive }\end{array}$ & $\begin{array}{c}\text { Oestrogen } \\
\text { Receptor } \\
\text { Negative }\end{array}$ \\
\hline $30-35$ yrs. & 0 & 0 \\
\hline $35-40$ yrs. & 2 & 1 \\
\hline $40-45$ yrs. & 4 & 5 \\
\hline $45-50$ yrs. & 8 & 5 \\
\hline $50-55$ yrs. & 5 & 0 \\
\hline $55-60$ yrs. & 4 & 1 \\
\hline $60-65$ yrs. & 2 & 2 \\
\hline $65-70$ yrs. & 1 & 0 \\
\hline Table 2: Age and Estrogen Receptor Status is Compared \\
\hline
\end{tabular}

$\mathrm{p}=0.462$ 


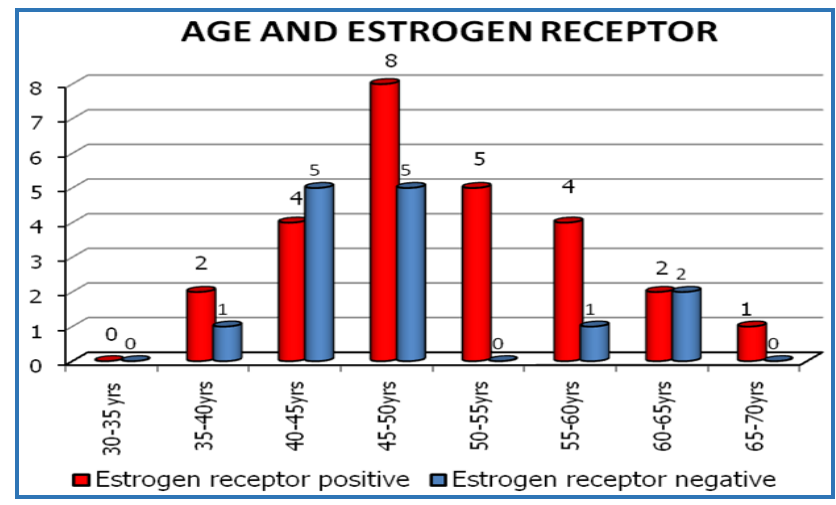

Here, the oestrogen receptor positivity/negativity is compared with the age of patient. A definitive positive correlation cannot be made as number of patients as a whole is more in the age group of $45-50$ yrs; still in the above considered patients, receptor positivity is persisting as the age increases. The statistical analysis is done using Fisher exact test, according to which the p value is 0.462 which is not significant.

\begin{tabular}{|c|c|c|}
\hline $\begin{array}{c}\text { Age of } \\
\text { Patients }\end{array}$ & $\begin{array}{c}\text { Progesterone } \\
\text { Receptor } \\
\text { Positive }\end{array}$ & $\begin{array}{c}\text { Progesterone } \\
\text { Receptor } \\
\text { Negative }\end{array}$ \\
\hline $30-35$ yrs. & 0 & 0 \\
\hline $35-40$ yrs. & 0 & 3 \\
\hline $40-45$ yrs. & 2 & 2 \\
\hline $45-50$ yrs. & 5 & 8 \\
\hline $50-55$ yrs. & 3 & 2 \\
\hline $55-60$ yrs. & 4 & 1 \\
\hline $60-65$ yrs. & 2 & 2 \\
\hline $65-70$ yrs. & 1 & 0 \\
\hline Table 3: Age and the Progesterone Receptor Status \\
\hline
\end{tabular}

$\mathrm{p}=0.402$

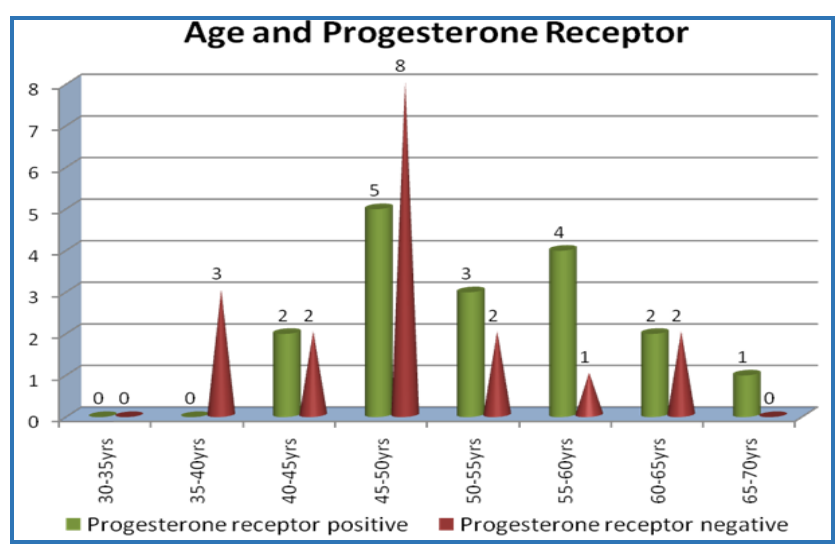

In case of the progesterone receptor, the negativity is maximum seen in 45-50 yrs. The study is done using the Fisher exact test and the $\mathrm{p}$ value is 0.402 , which makes the analysis insignificant.

\begin{tabular}{|c|c|c|}
\hline $\begin{array}{c}\text { Age } \\
\text { at Menarche }\end{array}$ & $\begin{array}{c}\text { Oestrogen } \\
\text { Receptor Positive }\end{array}$ & $\begin{array}{c}\text { Oestrogen } \\
\text { Receptor Negative }\end{array}$ \\
\hline 11 & 0 & 0 \\
\hline 12 & 2 & 1 \\
\hline 13 & 1 & 5 \\
\hline 14 & 10 & 17 \\
\hline 15 & 1 & 3 \\
\hline \multicolumn{2}{|c|}{ Table 4: Age of Menarche and Oestrogen Receptors } \\
\hline
\end{tabular}

$\mathrm{p}=0.590$

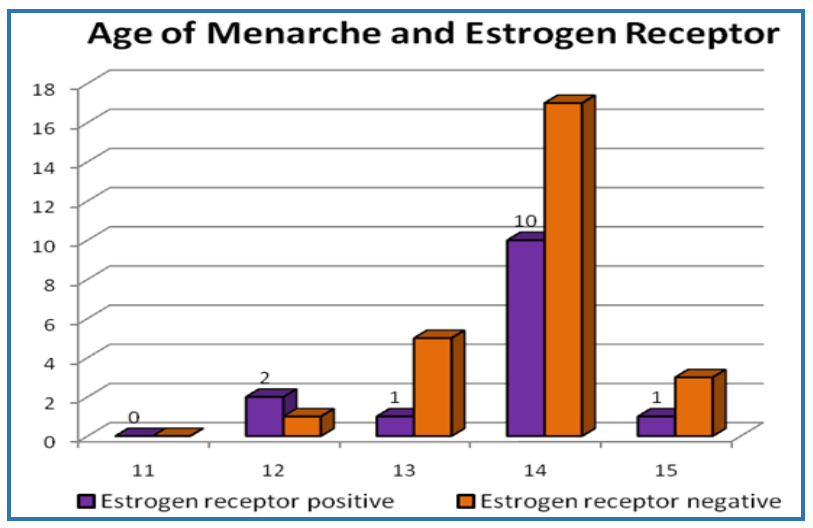

The study is done using the age, at which the women have attained their menarche and their oestrogen receptor status to find if there is any variation in the positivity/negativity at oestrogen receptor and age of menarche. The statistical analysis is done with Fisher exact test. The $\mathrm{p}$ value is 0.590 , which makes it insignificant.

\begin{tabular}{|c|c|c|}
\hline $\begin{array}{c}\text { Age } \\
\text { at Menarche }\end{array}$ & $\begin{array}{c}\text { Progesterone } \\
\text { Receptor Positive }\end{array}$ & $\begin{array}{c}\text { Progesterone } \\
\text { Receptor Negative }\end{array}$ \\
\hline 11 & 0 & 0 \\
\hline 12 & 1 & 2 \\
\hline 13 & 2 & 4 \\
\hline 14 & 10 & 17 \\
\hline 15 & 1 & 2 \\
\hline 16 & 0 & 1 \\
\hline \multicolumn{2}{|c|}{ Table 5: Age of Menarche and Progesterone Receptor } \\
\hline
\end{tabular}
$\mathrm{p}=0.999$

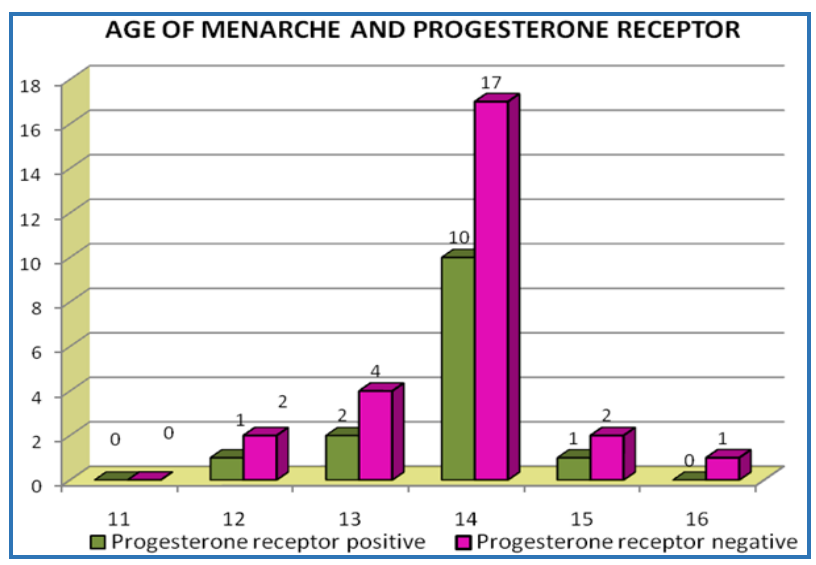

Here, the patient's age at menarche is compared with the progesterone receptor status. Most of the women attained their menarche at the age of 14 and most of them were progesterone negative. They were 17 in number. The statistical analysis was made using Fisher exact test. The $\mathrm{p}$ value was found to be 0.999 , hence it was insignificant.

\begin{tabular}{|c|c|c|}
\hline Parity & $\begin{array}{c}\text { Oestrogen } \\
\text { Receptor Positive }\end{array}$ & $\begin{array}{c}\text { Oestrogen } \\
\text { Receptor Negative }\end{array}$ \\
\hline 0 & 0 & 8 \\
\hline 1 & 2 & 1 \\
\hline 2 & 2 & 4 \\
\hline 3 & 4 & 6 \\
\hline 4 & 4 & 3 \\
\hline$>4$ & 3 & 3 \\
\hline \multicolumn{2}{|c|}{ Table 6: Parity and Oestrogen Receptors } \\
\hline
\end{tabular}

$\mathrm{p}=0.191$ 


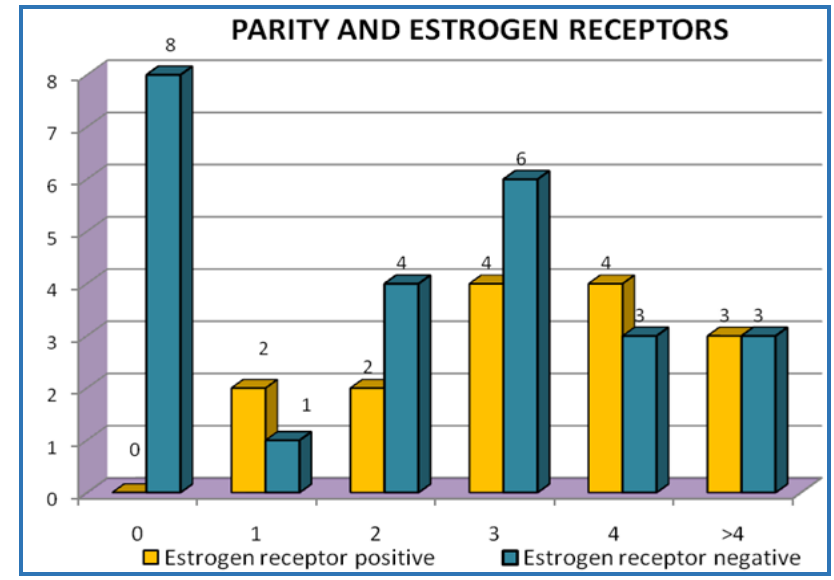

Here the study is done between the parity of the patient and the oestrogen receptor, which shows that among 8 nulliparous women in the study they were all oestrogen negative, as the parity has increased the oestrogen positivity has increased. The study was done using Fisher exact test and the $p$ value 0.191 and it was insignificant.

\begin{tabular}{|c|c|c|}
\hline Parity of Patient & $\begin{array}{c}\text { Progesterone } \\
\text { Receptor Positive }\end{array}$ & $\begin{array}{c}\text { Progesterone } \\
\text { Receptor } \\
\text { Negative }\end{array}$ \\
\hline 0 & 0 & 8 \\
\hline 1 & 2 & 2 \\
\hline 2 & 2 & 4 \\
\hline 3 & 3 & 6 \\
\hline 4 & 3 & 4 \\
\hline$>4$ & 4 & 2 \\
\hline \multicolumn{2}{|c|}{ Table 7: Parity and Progesterone Receptor Status } \\
\hline
\end{tabular}

$\mathrm{p}=0.155$

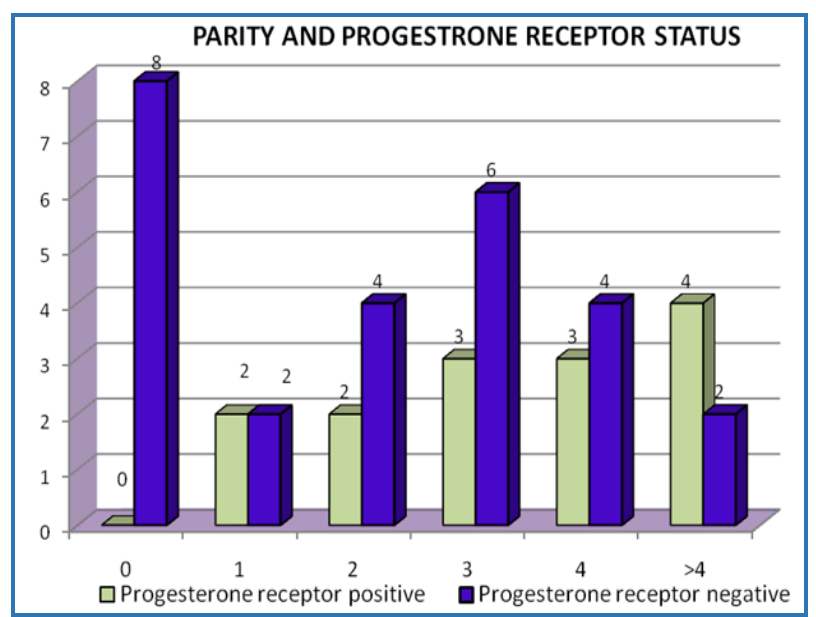

Here the study is done between the parity of the patients and the progesterone receptor, among the 8 nulliparous women they were all progesterone negative. The study is done using Fisher exact test. The $\mathrm{p}$ value was 0.155 and it was to be insignificant.

\begin{tabular}{|c|c|c|}
\hline Tumour Size & $\begin{array}{c}\text { Oestrogen } \\
\text { Receptor Positive }\end{array}$ & $\begin{array}{c}\text { Oestrogen } \\
\text { Receptor Negative }\end{array}$ \\
\hline$<2 \mathrm{cms}$ & 5 & 2 \\
\hline $2-5 \mathrm{cms}$ & 10 & 19 \\
\hline$>5 \mathrm{cms}$ & 0 & 4 \\
\hline \multicolumn{2}{|c|}{ Table 8: Tumour size and Oestrogen Receptor } \\
\hline
\end{tabular}

$\mathrm{p}=0.044$

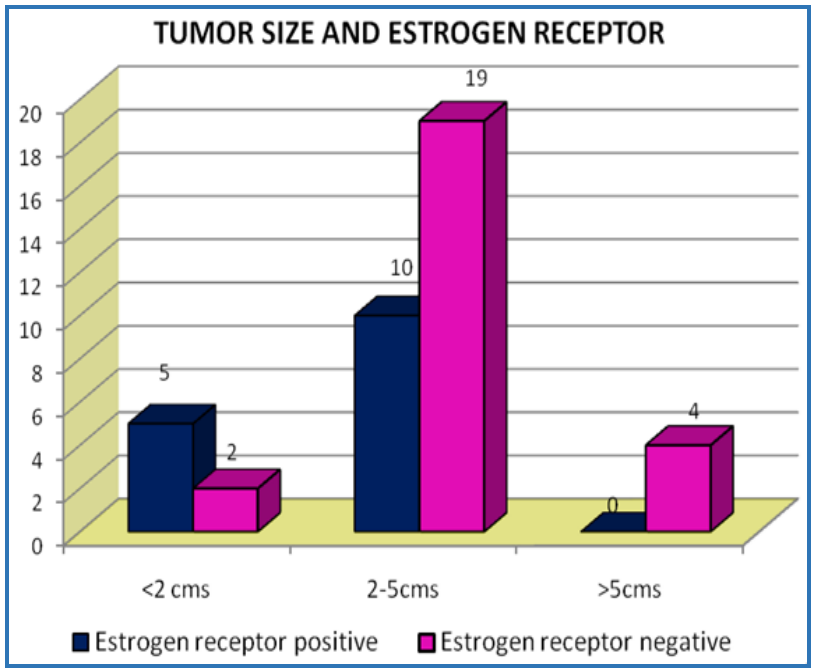

Here the study is done between the tumour size and the oestrogen receptor status, in this study most of the women had tumour in the range of $2-5 \mathrm{cms}$ and as the size of the tumour increased the oestrogen receptors negativity has increased. The statistics analysis is done using Fisher exact test and the $\mathrm{p}$ value was found to be 0.044 , hence the study was found to be significant.

\begin{tabular}{|c|c|c|}
\hline Tumour Size & $\begin{array}{c}\text { Progesterone } \\
\text { Receptor Positive }\end{array}$ & $\begin{array}{c}\text { Progesterone } \\
\text { Receptor Negative }\end{array}$ \\
\hline$<2 \mathrm{cms}$ & 5 & 3 \\
\hline $2-5 \mathrm{cms}$ & 9 & 19 \\
\hline$>5 \mathrm{cms}$ & 0 & 4 \\
\hline \multicolumn{2}{|c|}{ Table 9: Tumour size and progesterone receptor status } \\
\hline
\end{tabular}
$\mathrm{p}=0.044$

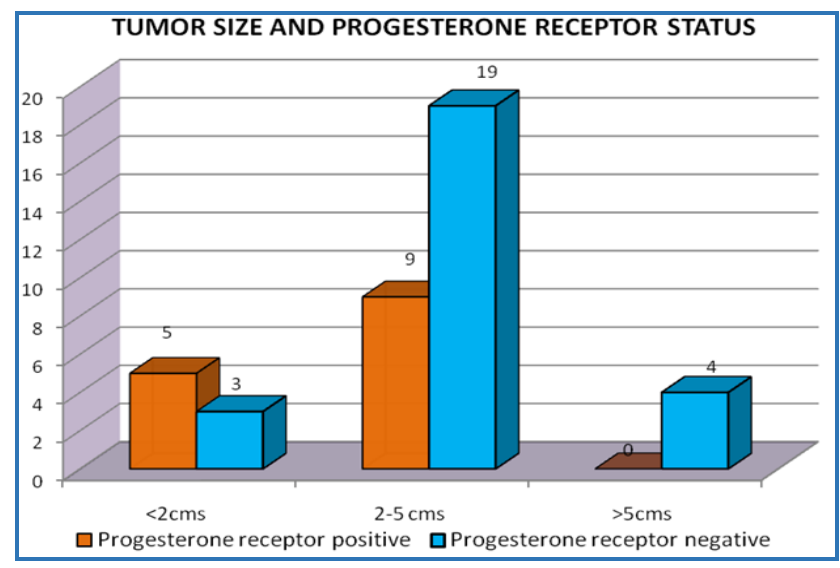

Here the tumour size and the progesterone receptor status is compared; most of the tumour are in the range of 2-5 $\mathrm{cms}$ and they are mostly progesterone negative and as the size increases the receptors are negative. The study is done using the Fisher exact test and the $\mathrm{p}$ value is found to be 0.044 and it is found to be significant.

\begin{tabular}{|c|c|c|}
\hline $\begin{array}{c}\text { Lymph } \\
\text { Node } \\
\text { Number }\end{array}$ & $\begin{array}{c}\text { Oestrogen } \\
\text { Receptor Positive }\end{array}$ & $\begin{array}{c}\text { Oestrogen } \\
\text { Receptor } \\
\text { Negative }\end{array}$ \\
\hline$<4$ & 7 & 5 \\
\hline $4-10$ & 3 & 20 \\
\hline$>10$ & 1 & 0 \\
\hline Table 10: Lymph Node Number and Oestrogen Receptors \\
\hline
\end{tabular}

$\mathrm{p}=0.008$ 


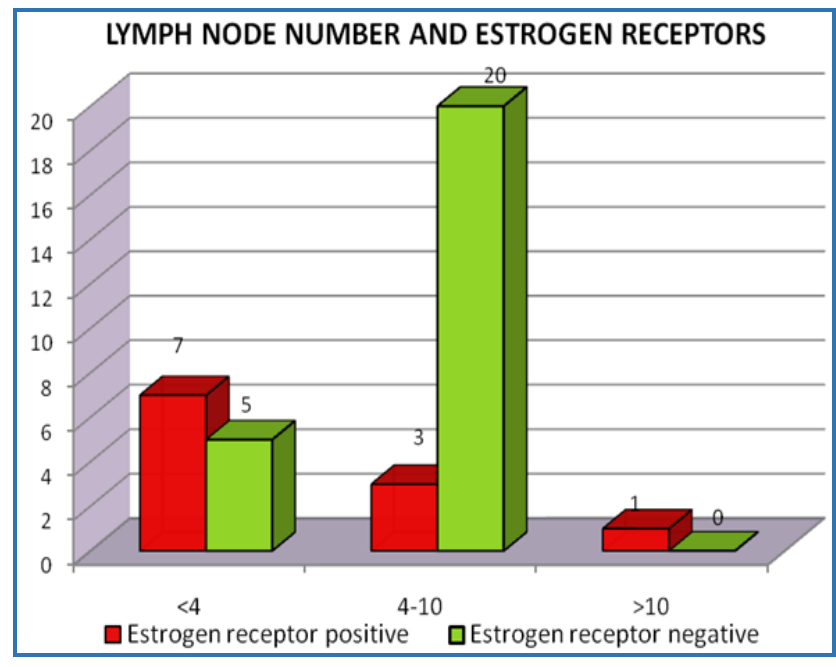

Here the lymph node size and the oestrogen receptor status is compared; in most of the cases the lymph node numbers were between 4 and 10 and they were mostly oestrogen receptor negative. The study was done with Fisher exact test and $p$ value was found to be 0.008 which is highly significant.

\begin{tabular}{|c|c|c|}
\hline $\begin{array}{c}\text { Lymph } \\
\text { Node Number }\end{array}$ & $\begin{array}{c}\text { Progesterone } \\
\text { Receptor } \\
\text { Positive }\end{array}$ & $\begin{array}{c}\text { Progesterone } \\
\text { Receptor Negative }\end{array}$ \\
\hline$<4$ & 6 & 6 \\
\hline $4-10$ & 5 & 18 \\
\hline$>10$ & 0 & 1 \\
\hline \multicolumn{2}{|c|}{ Table 11: Lymph Node Number and Progesterone Status } \\
\hline
\end{tabular}

$\mathrm{p}=0.044$

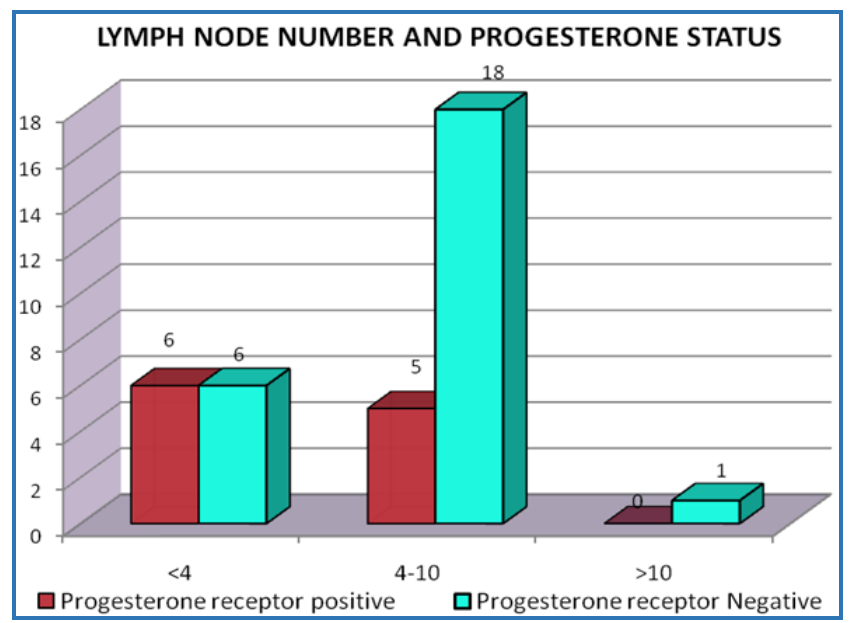

Here the lymph node number and the progesterone receptor status is compared; most of the women had 4 to 10 lymph nodes and they were mostly progesterone negative. The study was made using Fisher exact test and the $p$ value was found to be 0.044 and is significant.

\begin{tabular}{|c|c|c|}
\hline Tumour Grade & $\begin{array}{c}\text { Oestrogen } \\
\text { Receptor Positive }\end{array}$ & $\begin{array}{c}\text { Oestrogen } \\
\text { Receptor Negative }\end{array}$ \\
\hline Grade I & 2 & 0 \\
\hline Grade II & 13 & 20 \\
\hline Grade III & 0 & 5 \\
\hline \multicolumn{2}{|c|}{ Table 12: Tumour Grade and Oestrogen Receptor Status } \\
\hline
\end{tabular}

$\mathrm{p}=0.025$

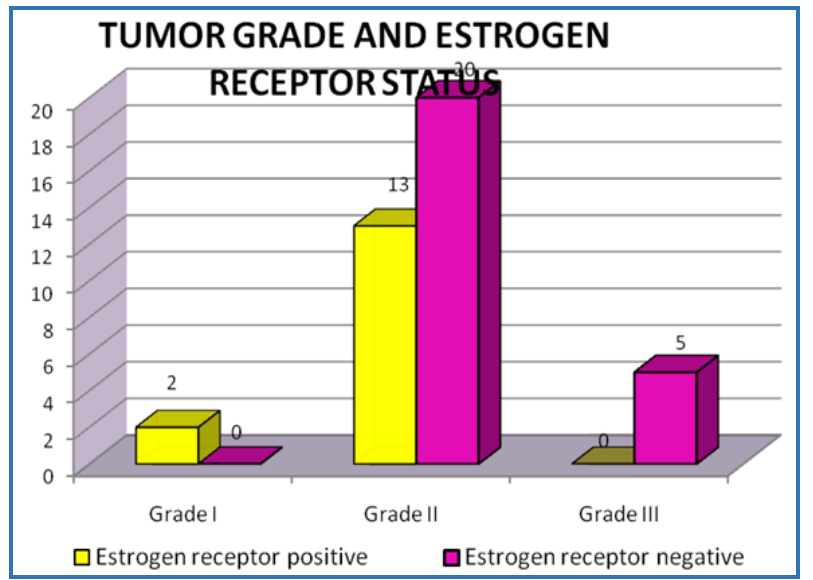

Here the grade of the tumour is compared with the oestrogen receptor status; in this study most of the cases were Grade 2 and they showed oestrogen receptor negative and the negativity is found to increase with increase in grade of the tumour. The statistical analysis is done using the Fisher exact test, which shows $\mathrm{p}$ value is 0.025 which makes the association between grade and oestrogen receptor significant.

\begin{tabular}{|c|c|c|}
\hline $\begin{array}{c}\text { Tumour } \\
\text { Grade }\end{array}$ & $\begin{array}{c}\text { Progesterone } \\
\text { Receptor Positive }\end{array}$ & $\begin{array}{c}\text { Progesterone } \\
\text { Receptor Negative }\end{array}$ \\
\hline Grade-I & 1 & 1 \\
\hline Grade-II & 13 & 20 \\
\hline Grade-III & 0 & 5 \\
\hline \multicolumn{2}{|c|}{ Table 13: Tumour Grade and Progesterone Status } \\
\hline
\end{tabular}
$\mathrm{p}=0.250$

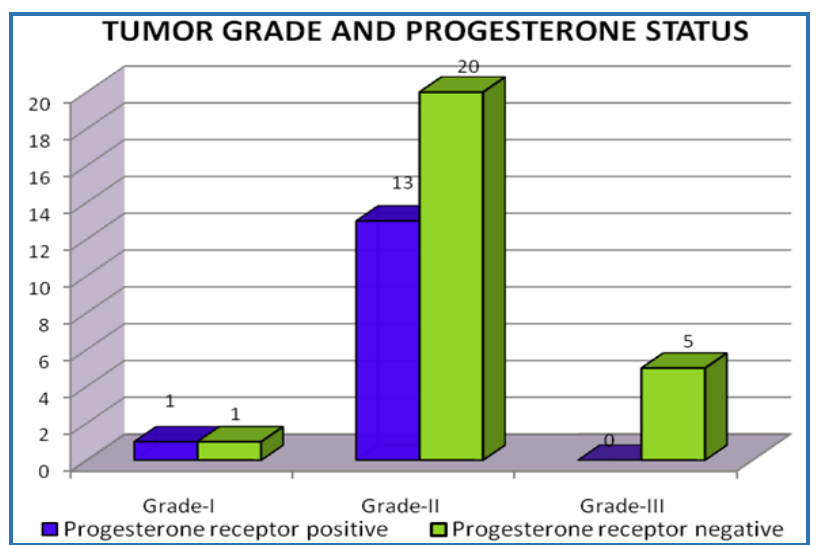

Here the graph compares the grade of the tumour and the progesterone status of the tumours; most of the tumours were grade 2 and most of them were progesterone negative, as the grade increases the negativity increase. The statistical analysis is done using Fisher exact test and the $p$ value is 0.250 , which makes it insignificant.

Menopause is compared with the oestrogen and progesterone status of the tumours, but this association was difficult as only 20 of the patients among 40 had attained menopause at the time of diagnosis.

\section{DISCUSSION}

Oestrogen and Progesterone Receptors in Breast Cancer in Black Americans Correlation of Receptor Data with Tumour Differentiation. 
A Study done by Mohala et al. in 1982. Study was done in 146 Black Women, Showed in Black Women

1. A low incidence of ER-positive (46\%) and high incidence of ER-negative (42\%) tumours.

2. A higher incidence of poorly differentiated (55.5\%) and a lower incidence of well differentiated (5.5\%) tumours; tumour grade was independent of age, menopausal status, histopathology and stage.

3. A higher percentage of patients discovered at a more advanced stage of the disease.

\section{Similar Finding as the Rest of the World Were}

1. Postmenopausal patients and primary tumours showed higher ER positivity than premenopausal patients and metastatic sites, respectively.

2. A significant correlation between the ER positivity and tumour grade.

3. A higher PgR positivity in ER-positive patients than in ERnegative patients. $6,7,8,9$

\section{HORMONE RECEPTORS}

\section{Association with Prognostic Factors for Breast Cancer}

A study done by Eisenberg et al. in $2001 .{ }^{10}$ data from 306 patients with infiltrating ductal carcinomas who were consecutively diagnosed and treated over a period of 20 months were included. Unconditional logistic regression revealed that the following variables were independent predictive factors of positivity of ER: age $>60$ years, histological Grade I, positive PR and negative p53. For PR, two models were evaluated:

a) Age $>60$ years, age at menarche $>11$ years and histological Grades I and II;

b) Histological Grades I and II and positive ER. In this study, only age at diagnosis, histological grade, PR and p53 were independent predictors of positivity of ER. Age at diagnosis, age at menarche and histological grade (or histological grade and ER) predicted a positive PR.

Immunohistochemical evaluation of human epidermal growth factor receptor- 2 and oestrogen and progesterone receptors in breast carcinoma in Jordan.

\section{A Study done by Almasri et al. in 2005.11 Considered 91 Cases showed that}

a) ER/PR negative cases were found to be more aggressive, larger primary tumour size, higher rate of axillary lymph node metastasis.

b) Oestrogen and progesterone receptor positive were less aggressive, responds to hormonal therapy and less chance of axillary lymph node metastasis. ${ }^{8}$

Oestrogen and progesterone receptors in human breast cancer. Correlation with histologic subtype and degree of differentiation.

\section{A Study done by Mohammed et al..$^{5}$ in University of} Minnesota in 2006 on 490 Cases of Breast Carcinoma

a) The less differentiated Grade III and Grade IV showed lower of oestrogen and progesterone receptors.

b) Patients younger than 53 yrs. with Grade II and III have lower level of oestrogen receptors, both not of progesterone receptors. ${ }^{5}$
This study has taken 40 women with breast carcinoma, who came to breast cancer clinic in the Department of Surgery.

Their detailed history was taken concerning their age of menarche, age of menopause, parity and their age. A detailed clinical examination was done, which gave information about tumour size and lymph node numbers. A histological grading is done using Modified Scarff Bloom Richardson. These features are compared with the oestrogen and progesterone status of the tumour specimen.

- Age group under study was from 30-70 yrs. among whom maximum women were in the age group 45-50 yrs., the mean age is $48 \mathrm{yrs}$. and standard deviation SD is +/_3.6.

- Comparing age and oestrogen receptor status using the Fisher exact test, the $\mathrm{p}$ value 0.402 , no significant inference could be made.

- Comparing age and progesterone receptor status using Fisher exact test with $p$ value 0.402 , no significant inference could be made.

- Menarche and oestrogen receptor status were studied in 40 women and it was analysed using Fisher exact test, $p$ value was 0.590 due to no significant inference could be made.

- Menarche and progesterone receptor status studied in 40 women showed most of them attained their menarche at the age of 14 , as the age increased there has been increase in progesterone negativity. Fisher exact test 0.999 , gives no significance.

- Parity and oestrogen receptor done in 40 women showed 8 of the nulliparous women were oestrogen negative, but the Fisher exact test done on the women showed $p$ value 0.191 , which does not give the study any significance.

- Parity and progesterone receptors studied among 40 women showed that nulliparous women were progesterone negative; using the Fisher exact test $p$ value was 0.155 , which made the comparison insignificant.

- Tumour size when compared with oestrogen receptor status in 40 women, most of them in the study had tumour size between 2 and $5 \mathrm{cms}$, most of them were oestrogen receptor negative and as the size increased the negativity has increased. The Fisher exact study showed $p$ value of 0.044 , making the comparison significant.

- Tumour size and progesterone receptor status is compared and an increase in negativity is seen as the size of the tumour increases. The Fisher exact test gives a $p$ value of 0.044 , making the comparison significant.

- Lymph node size and oestrogen receptors is compared and an increase in lymph node number showed increase in negativity of oestrogen receptors, the statistical analysis was done using Fisher exact test and the $p$ value is 0.008 and the comparison is significant.

- Lymph node number and progesterone receptor status shows that as the lymph node number increases the progesterone receptor becomes negative and the analysis is done using Fisher exact test. The p value is 0.044 , which makes this comparison significant.

- Tumour grading and oestrogen receptor status among the 40 women, most of the case were Grade 2 and they were mostly oestrogen negative. The analysis was done with Fisher exact test with $\mathrm{p}$ value 0.025 , it shows the comparison is significant. 
- Tumour grading and progesterone status showed that as the grade increased the negativity of the progesterone receptor increased. The Fisher exact test had $\mathrm{p}$ value of 0.025 , which made it significant.
- The menopause age could not be considered as among the 40 women taken, less than 20 only attained menopause and it did not show any relation to oestrogen or progesterone receptor status.

\begin{tabular}{|c|c|c|c|c|}
\hline Studies & Mohala et al. ${ }^{9}$ & Eisenberg et al.10 & $\begin{array}{c}\text { Almsari } \\
\text { et al.11,12,13,14,15 }\end{array}$ & Present Study \\
\hline Number of patients & 146 & 306 & 91 & 40 \\
\hline $\begin{array}{l}\text { Time duration of } \\
\text { study }\end{array}$ & 3 yrs. & $1 \mathrm{yr} 6 \mathrm{mths}$ & 4 yrs. & 1 yrs 6 mths \\
\hline Type of study & Prospective & Prospective & Retrospective & Prospective \\
\hline Mean age of patients & 54 yrs. & 54 yrs. & 46 yrs. & 48 yrs. \\
\hline $\begin{array}{l}\text { Age and oestrogen } \\
\text { receptor }\end{array}$ & $\begin{array}{c}\text { Negativity increase } \\
\text { with age }\end{array}$ & $\begin{array}{l}\text { Positivity increase with } \\
\text { age }\end{array}$ & $\begin{array}{c}\text { Positive case in } \\
\text { older patients }\end{array}$ & No significant relation \\
\hline Age and progesterone & $\begin{array}{c}\text { No significant relation } \\
\text { with age }\end{array}$ & $\begin{array}{l}\text { Positivity increase with } \\
\text { age }\end{array}$ & $\begin{array}{c}\text { Positive cases in } \\
\text { older patients }\end{array}$ & No significant relation \\
\hline $\begin{array}{l}\text { Menarche and } \\
\text { oestrogen }\end{array}$ & No significant relation & $\begin{array}{c}\text { As age increased } \\
\text { positivity increased }\end{array}$ & Not considered & No significant relation \\
\hline $\begin{array}{l}\text { Menarche and } \\
\text { progesterone }\end{array}$ & No significant relation & No significant relation & Not considered & No significant relation \\
\hline \multicolumn{5}{|c|}{ Table 14} \\
\hline
\end{tabular}

\begin{tabular}{|c|c|c|c|c|}
\hline Studies & Mohala et al.9 & Eisenberg et al.10 & Almsari et al.11 & Present Study \\
\hline $\begin{array}{c}\text { Parity and } \\
\text { oestrogen }\end{array}$ & Not considered & Not considered & Not considered & No significant relation \\
\hline $\begin{array}{c}\text { Parity and } \\
\text { progesterone }\end{array}$ & Not considered & Not considered & Not considered & No significant relation \\
\hline $\begin{array}{c}\text { Tumour size and } \\
\text { oestrogen }\end{array}$ & Not considered & $\begin{array}{c}\text { Smaller tumours } \\
\text { were positive }\end{array}$ & $\begin{array}{c}\text { Smaller tumours were } \\
\text { positive }\end{array}$ & $\begin{array}{c}\text { As size increased } \\
\text { negativity increased }\end{array}$ \\
\hline $\begin{array}{c}\text { Tumour size and } \\
\text { progesterone }\end{array}$ & Not considered & No significant relation & $\begin{array}{c}\text { Smaller tumours were } \\
\text { positive }\end{array}$ & $\begin{array}{c}\text { As size increased } \\
\text { negativity increased }\end{array}$ \\
\hline $\begin{array}{c}\text { Lymph node and } \\
\text { oestrogen }\end{array}$ & Not considered & Not considered & $\begin{array}{c}\text { Negative more } \\
\text { lymph nodes }\end{array}$ & $\begin{array}{c}\text { Negativity and lymph } \\
\text { node are directly related }\end{array}$ \\
\hline $\begin{array}{c}\text { Lymph node and } \\
\text { progesterone }\end{array}$ & Not considered \\
\hline $\begin{array}{c}\text { Tumour grade and } \\
\text { oestrogen }\end{array}$ & $\begin{array}{c}\text { As grade increase } \\
\text { more negative }\end{array}$ & $\begin{array}{c}\text { As grade increase } \\
\text { more negative }\end{array}$ & $\begin{array}{c}\text { As grade increase more } \\
\text { negative }\end{array}$ & $\begin{array}{c}\text { Negativity and lymph } \\
\text { node are directly related }\end{array}$ \\
\hline $\begin{array}{c}\text { Tumour grade and } \\
\text { negative } \\
\text { progesterone }\end{array}$ & $\begin{array}{c}\text { As grade increase } \\
\text { more negative }\end{array}$ & $\begin{array}{c}\text { As grade increase } \\
\text { more negative }\end{array}$ & $\begin{array}{c}\text { As grade increase more } \\
\text { negative }\end{array}$ & $\begin{array}{c}\text { As grade increase more } \\
\text { negative }\end{array}$ \\
\hline $\begin{array}{c}\text { Menopause and } \\
\text { oestrogen }\end{array}$ & $\begin{array}{c}\text { Menopausal patients } \\
\text { are negative }\end{array}$ & $\begin{array}{c}\text { Menopausal cases } \\
\text { are negative }\end{array}$ & Not considered & No significant inference \\
\hline $\begin{array}{c}\text { Menopause and } \\
\text { progesterone }\end{array}$ & $\begin{array}{c}\text { Menopausal patients } \\
\text { are negative }\end{array}$ & $\begin{array}{c}\text { Menopausal cases } \\
\text { are negative }\end{array}$ & Not considered & No significant inference \\
\hline
\end{tabular}

\section{CONCLUSION}

This was a prospective study and based on the study, the following conclusion can be arrived at,

- The oestrogen and progesterone receptor positive cases.

- Well differentiated.

- Less aggressive.

- Low lymph node metastasis.

- The oestrogen and progesterone, both negative or one of them negative.

- Moderately to poorly differentiated.

- More chances of lymph node metastasis.

- More aggressive.

The presence or the absence of these oestrogen or progesterone receptors will help people with breast cancer to decide on the type of treatment to be undertaken

The women with oestrogen and progesterone receptor positive status can opt for hormonal therapy, which will be beneficial for them. The women with oestrogen and progesterone receptor negative status, hormonal therapy will be ineffective.

\section{REFERENCES}

1. Birrell SN, Hall RE, Tilley WD. Role of the androgen receptor in human breast cancer. Journal of Mammary Gland Biology and Neoplasia 1998;3(1):95-103.

2. Payne SJ, Bowen RL, Jones JL, et al. Predictive markers in breast cancer the present. Histopathology 2008;52(1):8290.

3. Ferlay J, Bray F, Pisani P, et al. Globocan 2002. cancer

4. incidence, mortality and prevalence worldwide. IARC cancer base No. 5, version 2.0. IARC press, lyon, 2004.

5. Tewari M, Krishnamurthy A, Shukla HS. Predictive markers of response to neoadjuvant chemotherapy in breast cancer. Surg Oncol 2008;17(4):301-311. 
6. Mohammed HR, Lakatua DJ, Haus E, et al. Estrogen and progesterone receptors in human breast cancer. Correlation with histological subtype and degree of differentiation in university of Minnesota cancer cytopathology. Cancer Journal for clinicians 2006;58:1076-81.

7. Halsted WS. The results of operations for the cure of cancer of the breast performed at the Johns Hopkins hospital from June, 1889 to January 1894. Ann Surg 1894;20:497.

8. Richard Sainsbury. The breast, Bailey and Love Short practice of surgery. 25th edition, 2008;50:827-47.

9. Iglehart DJ, Smith LB. The breast, Sabiston text book of surgery. 18th edition, 2008;7:861-96.

10. Mohla S, Sampson CC, Enterline JP. Estrogen and progestrone receptors in breast cancer in black americans, correlation of receptor data with tumor differentiation. Cancer Journal 1982;50:552-59.

11. Eisenberg ALA, Koifman S. Hormone receptor association with prognostic factor for breast cancer. Revista Brasileria de Cancerologia 2001;47:49-58.
12. Almasri MN, Hamad M. Immunohistochemical evaluation of human epidermal growth factor receptor 2 and estrogen and progesterone receptors in breast carcinoma in Jordan. Breast Cancer Research 2005;7:598-604.

13. Harvey JM. Estrogen receptor status by immunohisto chemistry is superior to the ligand-binding assay for predicting response to adjuvant endocrine therapy in breast cancer. J Clin Oncol 1999;17:1474-81.

14. Dotzlaw H, Leygue E, Watson $P$, et al. Estrogen receptor- $\beta$ RNA expression in human breast tumor biopsies: relationship to steroid receptor status and regulation by progestins. Cancer Res 1999;59:529-32.

15. Clark GM, Harris JR, Lippman ME, et al. Prognostic and predictive factors: diseases of the breast, Lippincott, Williams \& Wilkins, Philadelphia. 2000;423-425.

16. ASCO Expert Panel. Update of recommendations for the use of tumor markers in breast and colorectal cancer. J Clin Oncol 1997;16:793-95. 